\title{
Conducive Classroom Environment: A Situational Analysis of Senior High Schools offering Clothing and Textiles in Ghana
}

\author{
Rosemary Quarcoo \\ Faculty of Home Economics, Clothing and Textiles Education Department \\ University of Education, Winneba, , Winneba, Ghana
}

\begin{abstract}
The study evaluated the conduciveness of Clothing and Textiles classroom environment for studies at the Senior High School level of Education in Ghana and sought to answer the following research questions: 1 . What is the view of teachers on the suitability of Clothing and Textiles classroom environment when classified in school categories? 2. What is the view of students on the suitability of Clothing and Textiles classroom environment when compared according to school categories? and the hypothesis $H_{01}$ : There is no statistical significant difference in the conduciveness of school environment when students are classified according to school options" was tested. An Evaluation research design was used in this study with a quantitative approach. A multistage sampling method (stratified, purposive and simple random techniques) were used to sample twenty-three teachers and four hundred and seventy-eight students from sixteen schools. The study revealed that, teachers and students disagreed $(M=2.37, S D=.96)$ and $(M=2.16, S D=1.0)$ respectively that, clothing and Textiles classroom environment was conducive for studying. The null hypothesis was rejected at a computed significant value of 0.05 . It is recommended that, Ministry of Education and Ghana education service should provide schools with adequate, efficient and modern classrooms and state-of-the-art Clothing and Textiles laboratories.
\end{abstract}

Keywords: Evaluation, Conducive, Classroom Environment, Clothing and Textiles, Senior High School

\section{Introduction}

Formal education takes place in a setting and this setting is mostly termed as the classroom/learning environment. Classroom / learning environment according to the [1] is the diverse physical locations, contexts, and cultures in which students learn.

The classroom environment is one of the factors that can make learning a success or deprive one of learning due to the fact that, children of school going age spend much time in the classroom [2]. Studies by The Research Alliance for New York City Schools in learning shows that, students who learn in a positive environment receives a month and a half more instruction than those in poor learning environment and this can lower teacher turnover by 25 percent. This is significant because teacher turnover has been linked to increase costs and poor student achievement. Schools that provide better environments, in other words, could potentially reach higher levels of success while spending less money [2].

Ryan 2013 also noted that, the way in which a teacher organizes their class, or how they control it, will yield positive or negative consequences for their students. If a teacher is unmotivated or negative, there will be a direct impact on the students within the classroom. Similarly, if a teacher is motivated and positive, they will likely have a beneficial impact on their students as well. It is therefore important for a teacher to understand this cause and effect in order to understand how to organize their classroom to create a better learning environment in order to help students gain an understanding of their place in the world by gaining required knowledge and skills. How desks are arranged, organization of the classroom developing rapport with students, availability of teaching and learning resources etc constituting the physical environment impacts teaching and learning [3]; [4]; [5]. Non-physical environment such as sound, temperature, light, seating arrangements, using higher academic achievers to enhance teaching and learning by pairing them with students that are lower performing or struggling with the specific content, the emotional environment created by the teacher and poor circulation of air [6]; [3] affects teaching and learning in diverse ways. The foregoing studies show that, the classroom environment plays a vital role in the success of teaching and learning.

The major rationale for teaching Clothing and Textile (CandT) in the Senior High School (SHS) is to train students acquire knowledge and skills in clothing production and management [7]. However, anecdotal evidence shows a gross display of ignorance and low interest by Senior High School students with CandT background who enter into the university.

Also, only a few students are able to make simple garments or textile articles after completion which makes those who are unable to further their education go through apprenticeship again before they can set up their own businesses [8]. Could it be that the classroom environment is not conducive enough since 
the is a major factor that can make or unmake the teaching and learning process?

To find an answer to this, Stufflebean's Context, Input, Process and Product (CIPP) curriculum evaluation model specifically the (Input) guided this study since the classroom environment, is part of the resources needed to implement a curriculum. There is not much evaluation research in this area hence this research was conducted to see the extent to which the environment in which Clothing and Textiles is offered is conducive.

\section{Research Questions}

i. What is the view of teachers on the suitability of Clothing and Textiles classroom environment?

ii. What is the view of students on the suitability of Clothing and Textiles classroom environment when compared according to school categories?

\subsection{Hypothesis}

$H_{01}$ : There is no statistical significant difference in the conduciveness of school environment when students are classified according to school options

\section{Methodology}

A descriptive research design was used for this study. A descriptive research specifies the nature of a phenomenon and it is important because it gives a picture of a situation or a population and any consideration of phenomena generally begins with a full understanding (description) of the phenomena. This helps in making a wide range of policy decisions [10].

In order to create a holistic view of how knowledge is viewed in this research, the pragmatic approach was adopted. Pragmatists believe that reality is constantly renegotiated, debated, interpreted, and therefore the best method to use is the one that solves the problem [9]. A mixed method of evaluation research was therefore undertaken in this investigation. Both qualitative and quantitative methods were used.

\subsection{Sampling procedure}

A multi stage sampling procedure was used. In the first stage, a stratified sampling technique was used to put the national distribution of the population into northern and southern zones. In stage two, purposive and simple random sampling techniques were used to get the regional distribution of population by selecting three regions from each zone. Two regions each were purposively selected (least and most number of schools offering Clothing and Textiles) and one school each were randomly selected in each zone to add up to three. In the third stage, a purposive and random selection of 18 schools from the six regions was made thus one school each was chosen from options 1,2 and 3 according to school categorization by Ghana Education Service in each region and the respondents were purposively selected for data collection.

\subsection{Instruments}

Questionnaire and observation checklist was used to collect data for the research

\subsection{Data analysis}

Data was analyzed using qualitative analysis methods and quantitative methods. The quantitative data collected was first of all, prepared and organized by editing in order to identify and eliminate errors made by respondents. The answers were recorded and data tabulated. Data was then analysed with the statistical package of social sciences. Data collected qualitatively was analyzed using thematic analysis.

\subsection{Ethical Considerations}

An official introductory letter was taken from the Dean, Faculty of Humanities and Social Sciences Education of the University of Cape Coast to the various schools and institutions to facilitate data collection. In addition, personal request letters were taken to all the SHS and WAEC help collect data for the study and all information needed e.g., from Ghana Education Service (GES) for the study.

Preliminary contacts were made with the headmasters and heads of Home Economics Department to discuss the purpose of the study and a convenient time for data collection. The purpose of the study was communicated to the respondents and they were assured of anonymity and confidentiality. Full consent of the respondents was sought before observation of the classroom environment. Students and teachers were accorded all the due respect. The study was conducted transparently and with all the honesty it deserves.

\section{Analysis of Findings and Results}

The suitability of the teaching and learning environment is crucial in the implementation of Clothing and Textiles curriculum. For this reason, the respondents were asked to indicate their level of agreement or disagreement to the statements measuring the conduciveness of Clothing and Textiles classroom environment. The analysis of the teachers' perspectives is summarised in Table 1. 
Table 1. Distribution of teachers' responses to conduciveness of the Clothing and Textiles classroom environment

\begin{tabular}{|c|c|c|c|c|}
\hline & Statements & $\mathrm{N}$ & Mean & $\begin{array}{l}\text { Std. } \\
\text { deviation }\end{array}$ \\
\hline 11 & $\begin{array}{l}\text { Clothing lab is big } \\
\text { enough to take all } \\
\text { equipment and } \\
\text { students during } \\
\text { classes. }\end{array}$ & 23 & 2.39 & 1.16 \\
\hline 12 & $\begin{array}{l}\text { Clothing lab has a } \\
\text { good lighting system. }\end{array}$ & 23 & 1.91 & .90 \\
\hline 13 & $\begin{array}{l}\text { Clothing lab is well } \\
\text { ventilated }\end{array}$ & 23 & 1.96 & .93 \\
\hline 14 & $\begin{array}{l}\text { I get distracted by } \\
\text { activities on campus } \\
\text { when having } \\
\text { Clothing and Textiles } \\
\text { classes }\end{array}$ & 23 & 2.91 & .95 \\
\hline 15 & $\begin{array}{l}\text { Electric wires are left } \\
\text { unattended to }\end{array}$ & 23 & 2.87 & 1.01 \\
\hline \multirow[t]{2}{*}{16} & $\begin{array}{l}\text { Students can freely } \\
\text { use the equipment in } \\
\text { the Lab }\end{array}$ & 23 & 2.17 & .78 \\
\hline & Mean of mean & 23 & 2.37 & .96 \\
\hline
\end{tabular}

In Table 1, teachers disagreed that clothing lab is big enough to take all equipment and students during classes $(\mathrm{M}=2.39, \mathrm{SD}=1.16)$. They also disagreed that clothing laboratory has a good lighting system $(\mathrm{M}=1.91, \mathrm{SD}=.90)$ and well ventilated $(\mathrm{M}=1.96$, $\mathrm{SD}=.93)$. The teachers also disagreed that students can freely use the equipment in the lab $(\mathrm{M}=2.17$, $\mathrm{SD}=.78$ ). In terms of safety, the teachers disagreed that electric wires are left unattended to in the lab $(\mathrm{M}=2.87, \mathrm{SD}=1.01)$. Regarding distraction of lessons, the teachers disagreed that they get distracted by activities on campus when having Clothing and Textiles classes $(\mathrm{M}=2.91, \mathrm{SD}=.95)$. The overall conduciveness of the learning environment $(\mathrm{M}=2.37$, $\mathrm{SD}=.96$ ) indicates that the environment was not conducive as reported by teachers.

\subsection{Students' responses on the conduciveness of the Clothing and Textiles classroom environment}

The students were asked to report on the suitability of the learning environment. A total of seven (7) items were presented. The students in the three options marginally agreed that Clothing and Textiles laboratory is big enough to take all equipment and students during classes $(\mathrm{M}=2.52, \mathrm{SD}=1.18)$. The student further agreed that they get distracted by activities on campus when having Clothing and
Textiles class $(M=2.75, S D=1.10)$. Furthermore, the students agreed that electric wires are left unattended to in the laboratory $(\mathrm{M}=3.12, \mathrm{SD}=.95)$. There was marginal disagreement on free movement and use of equipment in the laboratory $(\mathrm{M}=2.49, \mathrm{SD}=1.09)$ among students. The students also disagreed that Clothing and Textiles teachers are friendly $(\mathrm{M}=1.47$, $\mathrm{SD}=.66$ ), the Clothing and Textiles laboratory is well ventilated $(M=2.23, S D=1.12)$ and has a good lighting system $(\mathrm{M}=2.24, \mathrm{SD}=1.11)$.

To examine whether students' reported perspectives on conduciveness of environment have reached statistical significance, a one-way analysis of variance (one-way ANOVA) test was conducted.

$* p<0.05$ (2-tail significant results). The ANOVA results revealed significant difference in five (5) out of seven (7) statements measuring the conduciveness of environment from the perspectives of the students. Specifically, significant difference was ascertain on the statement "Clothing and Textiles laboratory is big enough to take all equipment and my mates during classes" $(F(2,475)=7.241, p=0.001)$, "Clothing and Textiles laboratory has a good lighting system" $(\mathrm{F}(2,475)=8.519, \mathrm{p}=0.00)$, and "Clothing and Textiles laboratory is well ventilated" $(\mathrm{F}(2,475)=$ 5.870, $\mathrm{p}=.003)$. Also, there is significant mean difference in students' response to the statement "I get distracted by activities on campus when having Clothing and Textiles classes" $(\mathrm{F}(2,475)=3.693$, $\mathrm{p}=.026)$ and "Electric wires are left unattended to" (F $(2,475)=6.004, p=.003)$. To check where the differences in the means are located in the distribution, a Post Hoc analysis was conducted using Tukey HSD test.

The results of the post hoc comparisons using Turkey HSD test revealed that statistical significant differences exist among students regarding their perceptions on whether Clothing and Textiles laboratory is big enough to take all equipment and students during classes in Option $1(\mathrm{M}=2.70$, $\mathrm{SD}=1.20)$ and Option $3(\mathrm{M}=2.26, \mathrm{SD}=1.12)$ schools. Also, students from Option 1 schools $(\mathrm{M}=2.42$, $\mathrm{SD}=1.12$ ) differ significantly in terms of their perception on whether Clothing and Textiles laboratory has a good lighting system from Option 3 schools $(\mathrm{M}=1.94, \mathrm{SD}=.96)$. Likewise, students in Option 2 schools $(\mathrm{M}=2.32, \mathrm{SD}=1.18)$ also differ significantly from students in Option 3 schools $(\mathrm{M}=1.94, \mathrm{SD}=.96)$. There was significant difference in students' responses to the statement on "Clothing and Textiles laboratory is well ventilated" between Option 1 schools $(\mathrm{M}=2.44, \mathrm{SD}=1.18)$ and Option 2 schools $(\mathrm{M}=2.12, \mathrm{SD}=1.12)$. Similar trend was recorded between students from Option 1 schools $(\mathrm{M}=2.44, \mathrm{SD}=1.18)$ and Option 3 schools $(\mathrm{M}=2.07$, $\mathrm{SD}=1.02)$. Students in Option 2 schools $(\mathrm{M}=2.90$, $\mathrm{SD}=1.05)$ differ significantly from students in Option 1 schools $(\mathrm{M}=2.24, \mathrm{SD}=1.11)$ on the statement "I get distracted by activities on campus when having 
Clothing and Textiles classes". Finally, students in Option 3 schools $\quad(\mathrm{M}=3.21, \quad \mathrm{SD}=.95)$ differ significantly from students in Option 1 schools $(\mathrm{M}=2.91, \mathrm{SD}=1.05)$ on the free use of equipment in the Clothing and Textiles laboratory. Similar difference was established between students in Option 2 schools $(\mathrm{M}=3.25, \mathrm{SD}=.99)$ and Option 1 schools $(\mathrm{M}=2.91, \mathrm{SD}=1.05)$ concerning the use of equipment in the laboratory.

The rest of the mean difference between the groups existed due to chance. The null hypothesis, "There is no statistical significant difference in conduciveness of environment when students are classified according to school Options" is subsequently rejected at a computed significant value of 0.05 .

\section{Discussion}

The teachers' response on the conduciveness of the learning environment shown that, the learning environment was not all that good $(\mathrm{M}=2.37, \mathrm{SD}=.96)$ for learning but they had no option than to make do with what they have. Many studies have shown that learning in a conducive classroom environment can impact on learning negatively or positive as mentioned by The Research Alliance for New York City Schools in [2] that, the classroom environment is one of the factors that can make learning a success or deprive it because, a large amount of the child's time is spent sitting in a school classroom thus students who learn in positive environments effectively receive a month and a half more instruction than those in poor learning environments, lower teacher turnover by 25 percent. This was reiterated by [3] that, the classroom is a place where students learn the various skills deemed necessary, gain understanding of their place, develops and crafts their future, as well as gain knowledge of the skills needed to reach that goal. For these and more reasons the environments have a crucial place in the teaching and learning situation since it can make or unmake education.

\subsection{Student's view on conduciveness of classroom environment}

The students reported that, they get distracted by activities on campus. Sound plays a very important role in the attention and success of a student example a student tapping their pencil repeatedly on the desk can greatly distract another [6].

It was noted that the classrooms were not well ventilated, did not have a good lighting system and electrical wires were left hanging. A personal observation confirms that the lighting systems in the corners created for Clothing and Textile classes and the classrooms that are rotated were not well lit and not well ventilated but those who found themselves in the dining halls had good ventilation. These affect teaching and learning greatly since according to [6], lighting system, temperature and air circulation can determine whether or not a student is engaged in the lesson. Observations made in the school revealed that, most Clothing and Textiles students do not have permanent classrooms hence during CandT classes, some students are seen carrying sewing machines to free spaces within the school premises. Some schools have CandT classes on corridors, in dining halls etc.

The report indicates that, teachers are not friendly. Research shows that, the emotional atmosphere created by a teacher can make or unmake a lesson for example, [3] states that the emotional environment or atmosphere created by the teacher can either encourage or discourage students to be successful. He argued that the emotional environment is laced into every other section of education when talking about the benefits or harms experienced by the students.

\section{Conclusion}

The results of this research revealed that there is a statistical difference in the conduciveness of school environments based on school options. Generally, students from option 1 schools differed significantly on their perception in most of the statements measuring the conduciveness of the school environment positively showing that, this school category has a better teaching and learning environment than options 2 and 3.

The classroom is such an important place in the growth of a child for that matter the cohort of individuals who are currently in the Senior High Schools offering Clothing and Textiles (Generation Z) who are skill focused and prefers safe, technologically resourced and useful environment for learning. It is therefore important to understand the ways in which to affect this environment in order to receive maximum effectiveness in instruction.

Due to poor teaching and learning environment, teachers are unable to teach all concepts very well to students and they find it difficult to get the best out of Clothing and Textiles lessons. A conducive Clothing and Textile classroom environment will bring about easy and better teaching and learning, easy and convenient practical sessions, good student teacher relationship which will all lead to the attainment of the goals of teaching Clothing and Textiles in Ghana. Creating a conducive teaching and learning environment is one of the ways in which schools can enhance teaching of the next generation to enable them to become successful members of society.

\section{Recommendation}

The Ministry of Education and Ghana Education Service should provide schools with state-of-the-art Clothing and Textiles classrooms and laboratories. 


\section{References}

[1] Glossary of Educational Reform (2014). What is a Learning Environment? https://opentextbc.ca/teachinginad igitalage/chapter/5-2-what-is-a-learningenvironment/on2010-2020. (Access Date: 12 September 2021).

[2] Leaning Liftoff, (2016). How a School's Learning Env ironment Affects Student Achievement, https://www.learni ngliftoff.com/how-aschools-learning-environment-affectsst udent-achievement/. (Access Date: 22 October 2021).

[3] Ryan, H. (2013). Effect of classroom environment on student learning. Honors Thesis2375. Retrieved from https://scholarworks.wmich.edu/honors_theses/2375. (Acc ess Date: 11 October 2021).

[4] Grubaugh, S., and Houston, R. (1990). Establishing a classroom environment that promotes interaction and improved student behavior. The Clearing House, 63(8), 375-378.

[5] Guardino, C. A., and Fullerton, E. (2010). Changing behaviors by changing the classroom environment. Teaching exceptional children, 42(6), 8-13.

[6] Burke, K., and Burke-Samide, B. (2004). Required Changes in the classroom environment It's a Matter of Design. The Clearing House: A Journal of Educational Strategies, Issues and Ideas, 77(6), 236-240.

[7] Ministry of Education. (2010). Teaching syllabus for Clothing and Textiles: Senior High School $1-3$. Accra, Ghana: Ministry of Education Publication.

[8] Oppong, J. A., Biney-Aidoo, V., and Antiaye, V. (2013). Evaluating the benefits of computer aided-design (CAD) in Fashion Education, the Case of Accra Polytechnic. Journal of Education and Practice, 4(21), 73-80.

[9] Patel, S. (2015). The research paradigm - methodology, epistemology and ontology - explained in simple language. http://salmapatel.co.uk/academia/the-research-paradigm-m ethodology-epistemology-and-ontology-explained-in-simp le-language/. (Access Date: 26 November 2021).

[10] Osuala, E. C. (2005). Research Methodology. Enugu: New Generation Books. 